\title{
OPENING BLACK BOXES OF DISRUPTIVE INNOVATIONS: CONTROVERSIES INVOLVING UBER IN BELO HORIZONTE
}

\author{
KELLY C. VIEIRA ${ }^{1}$ \\ (D) https://orcid.org/0000-0001-7325-0615 \\ ANDRÉ L. PAIVA ${ }^{1}$ \\ (iD) https://orcid.org/0000-0002-7895-730X \\ VALDERÍ C. ALCÂNTARA ${ }^{2}$ \\ (iD) https://orcid.org/0000-0002-6698-0609 \\ DANIEL C. REZENDE ${ }^{1}$ \\ (iD) https://orcid.org/0000-0003-1277-724X
}

To cite this paper: Vieira, K. C., Paiva, A. L., Alcântara, V. C., \& De Rezende, D. C. (2020). Opening black boxes of disruptive innovations: Controversies involving Uber in Belo Horizonte. Revista de Administração Mackenzie, 21 (3), 1-25. doi:10.1590/1678-6971/eRAMR200018

Submission: Feb. 10, 2019. Acceptance: Sept. 20, 2019.

1 Federal University of Lavras (Ufla), Lavras, MG, Brazil.

2 Minas Gerais State University (UEMG), Cláudio, MG, Brazil.

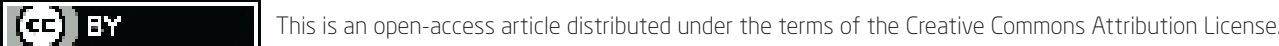

\footnotetext{
This paper may be copied, distributed, displayed, transmitted or adapted if provided, in a clear and explicit way, the name of the journal, the edition, the year and the pages on which the paper was originally published, but not suggesting that RAM endorses paper reuse. This licensing term should be made explicit in cases of reuse or distribution to third parties. It is not allowed the use for commercial purposes.

Este artigo pode ser copiado, distribuído, exibido, transmitido ou adaptado desde que citados, de forma clara e explícita, o nome da revista, a edição, o ano e as páginas nas quais o artigo foi publicado originalmente, mas sem sugerir que a RAM endosse a reutilização do artigo. Esse termo de licenciamento deve ser explicitado para os casos de reutilização ou distribuição para terceiros. Não é permitido o uso para fins comerciais.
} 


\section{ABSTRACT}

Purpose: This article aims to understand the controversies present from the insertion of a disruptive technology in a new business model, Uber, in the urban mobility market of Belo Horizonte-MG.

Originality/value: The actor-network theory allows us to describe innovation as technical and social, as well as to identify the sociomaterialities that enact and multiple realities from controversies in dispute. The proposal is original in investigating how a disruptive innovation is built as a "fact", accompanying its stabilization processes.

Design/methodology/approach: The research was operationalized from the actor-network theory itself, using cartography to follow the actors in their controversies. The data came mainly from newspapers, postings on social networks and legal materials accessed through the internet (from December 2014 to July 2017). For the presentation of the results, the mandala of actors who dispute positions in controversies and the hierarchical tree of the controversies were used.

Findings: The arrangement was marked by several controversies that deal with the legitimacy of the application, the labor relations established by the innovation and the quality of the services provided, each supported by different actors, positions and arguments. Four types of technology identified in this arrangement were identified: 1 . user technology; 2 . service provision; 3. economic issues; and 4. Uber driver. It is understood, therefore, that the technology has multiple dimensions and is enacted of different forms, and that this arrangement has not yet stabilized.

\section{KEYWORDS}

Cartography of controversies. Sharing economy. Actor-network theory. Technology and society. Enactment. 


\section{INTRODUCTION}

In the processes of disruptive innovations, the understanding of sociomateriality plays a central role, given that, according to Mol (2002), it enacts reality. In this way, the description of disruptive innovations from the perspective of the actor-network theory (ANT) poses a challenge that goes beyond the traditional proposals of study in this field, considering explicitly that the "design of a technology is an endless process" (Callon, 2004, p. 3).

In methodological terms, the challenge is to identify the sociomateriality that is enacting the multiple realities. In the view of the ANT, reality and the social are co-produced by sociomaterial commitments. This view assumes that innovation is both technical and social as science and technology, as well as society and technology being embedded (Latour, 2012). In this research, it is understood that such imbrications are present in the disruptive innovation process enacted by the US Uber company, which provides a platform for the provision of paid transportation services (e-hailing) from third-party cars.

To understand this process, the notion of symmetry (Latour, 2012) imposes itself against most studies on disruptive innovations that focus on technical and technological aspects, as if they were separate or not part of the social aspects. The ANT faces these binarisms and dichotomies in favor of the understanding of sociotechnical networks and agencies. This perspective has been used in studies of science, technology, and society (Tonelli, 2016), in which it arises, and more recently in consumer research and market building (Callon \& Muniesa, 2005; Kjellberg \& Helgesson, 2006; Araujo, 2007; Çalışkan \& Callon, 2010). Thus, the present study is inserted as a hybrid object (Latour, 2012) of the discussions on science and technology on the one hand, and the construction of markets from Uber's disruption processes on the other hand.

The research context is marked by the urban mobility market, understanding the market as the result of a continuous process involving materially heterogeneous entities - a hybrid collective (Kjellberg \& Helgesson, 2006). The article also found that "material objects, even human agents, play active roles in the formation of the market" (Medeiros, Vieira, \& Nogami, 2014, p. 158). In the case of the urban mobility market today, it involves (after destabilization) a variety of human and non-human elements, such as taxis, public buses, subways, unions, cooperatives, private cars, laws, car rentals, GPS, special roads, apps, companies, drivers, passengers, 
regulations, and working conditions, among others (Binenbojm, 2016): a diversity of actors that translate diverse and contradictory interests (Latour, 2012). Therefore, controversies emerged in the constitution of Uber in this market, specifically in the city of Belo Horizonte-MG.

The technology provided by Uber (Uber do Brasil Tecnologia Ltda.) is not yet a process of innovation established, regulated, and regularized in this capital. Belo Horizonte already had (before the application insertion) stabilization in the urban mobility market, being the taxi and public transportation the central actors of the established order. This is what makes this study more relevant, given that the Uber application (app) has sparked controversies that have not yet stabilized; that is, the construction of a black box (stabilization) that purifies the process of the multiplicity of divergent interests has not yet occurred. Or more simply, the Uber model is not yet seen as natural/given or unquestionable. When the black box closes, Uber will become a natural and accepted market practice, without controversy around its existence. Another possibility is also that it ceases to exist. In any case, its controversial history will no longer be relevant from that moment on. While this is not happening, we realize in this research that the insertion of Uber into the market was marked by uncertainties and controversies (Latour, 2012) and destabilization (Medeiros et al., 2014) of the urban mobility market.

To reveal these processes, one of the ways is the study of controversies that allows a description of the involvement of different actors and the heterogeneity of the sociotechnical networks, as well as the various debates and confrontations (Venturini, 2010; Latour, 2012) involved in the case of Uber. Prior to this study, Blanchet and Depeyre (2016, p. 4) have already pointed out that controversies "are useful methodological devices for studying the diffusion of innovations, the qualification of goods and the emergence, transformation and decline of markets." They are important for tracking connections (Latour, 2012). Based on this understanding, we seek in this article to understand the present dispute from the insertion of a disruptive technology in a new business model (Uber) into the urban mobility market of Belo Horizonte-MG. For this, the controversies present in this market were mapped and the network actors that perform them were presented.

Regarding the choice of object, we justify it in the words of Venturini (2010, p. 13), "one should look for controversies where everyone is shouting and fighting; where conflicts grow most severely." In this sense, Belo Horizonte was one of the places where Uber had the most controversy surrounding its existence. 


\section{THE STUDY OF CONTROVERSIES FROM THE ACTOR-NETWORK THEORY}

ANT breaks with many of the previous visions of social theory by markedly introducing the importance of the artifacts and objects in the understanding of social life beyond the dichotomous separations of "society and nature," "social and natural," or "technique and science." From the perspective of human and non-human, the ANT is actant. Latour (2012) argues that nonhuman actors (such as objects) directly interfere with the effects of meaning in the course of the phenomena surrounding the reality construction process, and human interactions are constantly mediated and shaped by non-human actors. Therefore, ANT is marked by a procedural view of the hybrid entities that make up the collectives (Callon, 1986; Latour, 2012).

The ANT also works with the stability of sociotechnical objects in a different way, not perceiving it as something inherent in materials. This is critical to understand the field of studies on innovation and marketing, as an innovative process becomes stabilized and as markets are built (Callon \& Muniesa, 2005; Kjellberg \& Helgesson, 2006; Araujo, 2007; Çalışkan \& Callon, 2010).

Regarding the construction of markets based on ANT, Çalışkan and Callon (2010) show that the notion of sociotechnical agency allows us to understand how the action takes place in hybrid collectives, composed of humans, materials, texts, and devices, among other actors. Thus, collective action is shared between sociomaterial entities. This view also goes beyond the notion of innovation from an individual actor, as very naively put in the case of entrepreneurs. This is evident in the process described by Latour (2016) of a sociotechnical innovation: the birth control pill. For him, innovation came from the interests of actors, such as the feminist activist Margaret Sanger, the chemist Gregory Pincus, the wealthy widow Catherine Dexter McCormick, and molecules (steroids). That is, the ability to act is acquired in relation to different elements (Latour, 2016).

To understand the processes, it is necessary to follow or map the controversies (Latour, 2012, 2016). For Latour (2016), in the controversies, we identify the ways in which actors construct and modify "facts." In the controversies, "intervening actors develop contradictory arguments and viewpoints that lead them to propose different versions of the social and natural worlds" (Callon, 1986, p. 3). Therefore, controversy cartography seeks to bring together different points of view, in which confrontations are observed in the search for the definition of the object - in our case, the Uber 
app. For this, from the perspective of market building, Araujo (2007) states that a wide range of practices should be considered, such as regulatory efforts, scientific work, and everyday actors, among others.

The analysis of controversies (Venturini, 2010) allows the understanding of disputes arising from different interests, constituted through translations. Controversies are disputes and conflicts, the study of which reveals the diversity of the interests mobilized, since in the controversies "groups and anti-groups arise in conflict with opposing positions in the debate" (Cerretto \& Domenico, 2016, p. 91). This type of conflict is used to "track social connections" (Latour, 2012, p. 53).

In general, Venturini (2010) explains that, at the moment that agents face a lack of consensus on a certain event, action, or project and join forces in the dissemination and propagation of their arguments in order to convince other agents, controversy is in place. Describing the controversies, it is possible to perceive the "many changing frames of reference" (Latour, 2012, pp. 53-54) in the process of forming human and non-human collectives.

\section{METHODOLOGICAL APPROACHES}

The research was carried out from the ANT, which, according to Latour (1999, p. 20), is "a method, not a theory," or "a very crude method for learning about actors without imposing an a priori definition of their ability to worldbuilding." Therefore, the strategy was to follow the actors, in their controversies, performing in the urban mobility market in Belo Horizonte-MG.

Among the options for analyzing controversies from the perspective of the ANT, Latour (2012) highlights the possibility of adopting the concept of cartography, used to record and analyze the different moments of translation often present in change processes. Cartography has been developed and adopted by Bruno Latour over time and was used as an option for the treatment and analysis of data in this study, following the indications of Venturini (2010). The procedures adopted were also based on the use of the notion of controversies by Cerretto and Domenico (2016) and Moraes, Andion, and Pinho (2017).

Data collection was performed through documentary research from data available on the internet. In this way, we tracked the controversies that marked the urban mobility market in Belo Horizonte involving Uber. For Venturini (2010), only by accumulating notes, documents, interviews, surveys, archives, experiences, and statistics can researchers make an attempt to describe collective life. 
Considering the foundations of the mentioned authors, data collection began by selecting reports published in the two most widely circulated newspapers in Belo Horizonte: O Tempo and Estado de Minas. The first requirement, proposed by Latour (2012), is not to simplify the number of propositions to be considered in the discussion. As a result, the reports led to a multiplicity of actors about whom, as we walked in understanding their positions on the network, we gathered more analytical materials, with the inclusion of other information, such as vehicles, public documents, videos, social networks, and company data.

In total, 156 newspaper reports were collected (in the vehicles: O Tempo, Estado de Minas Gerais, G1, Business Insider, Tech Crunch); three Bills (2,676/15, 1647/15, 5587/16); two municipal laws (Law 1,797/15 and Law 10,900/16); four documents published in the Official Gazette of the Municipality of Belo Horizonte and the Public Prosecution Service in the form of a Public Note; four private and/or public company websites (WillGo, Sincavir, BHTrans, and Uber) and 106 minutes of video material (lectures, interviews, reports, and conferences published on their official pages via Facebook). Comments were also read from news reports and posts on the social network Facebook (in groups of users and drivers of the app, pages of the mobilized actors), and four trips were carried out (one of them by Cabify, two by Uber, and one by Taxi) as a researcher's experience, establishing informal conversations about this market, the Uber app, its repercussions, and the influence and the positioning of the actors involved. Therefore, the actors were followed in the controversies from December 2014 (date of start of Uber operations in Belo Horizonte) to July 2017 (moment of data collection closure).

The sources referenced directly in the results are coded from R1 to R21 in Figure 3.1 - indicating the main events of the controversies.

\section{(Figure 3.1)}

\section{MAIN DATA SOURCES COVERED FOR MAPPING OF ACTORS AND CONTROVERSIES CONFIGURATION}

\begin{tabular}{cl}
\hline CD & Access links to key documents \\
\hline R1 & $\begin{array}{l}\text { https://www.ted.com/talks/travis_kalanick_uber_s_plan_to_get_more_people_into_fe } \\
\text { cars?language=pt-br }\end{array}$ \\
\hline R2 & http://www.businessinsider.com/uber-helicopter-rides-from-nyc-2013-7/ \\
\hline R3 & https://techcrunch.com/2011/05/25/uber-airbnb-jail-time/ \\
\hline R4 & $\begin{array}{l}\text { https://techcrunch.com/2013/01/31/a-day-after-cutting-a-deal-with-lyft-california- } \\
\text { regulator-reaches-an-agreement-with-uber-as-well/ }\end{array}$ \\
\hline
\end{tabular}




\section{(Figure 3.1 (conclusion))}

MAIN DATA SOURCES COVERED FOR MAPPING OF ACTORS AND CONTROVERSIES CONFIGURATION

\begin{tabular}{|c|c|}
\hline$C D$ & Access links to key documents \\
\hline R5 & $\begin{array}{l}\text { http://www.otempo.com.br/cidades/projeto-que-pro\%C3\%ADbe-o-uber-recebe-parecer- } \\
\text { favor\%C3\%Alvel-1.1091126 }\end{array}$ \\
\hline R6 & https://www.facebook.com/EstadodeMinas/ \\
\hline R7 & $\begin{array}{l}\text { http://www.otempo.com.br/cidades/pbh-pretende-criar-t\%C3\%Alxi-premium-no-lugar-do- } \\
\text { uber-1.1129430 }\end{array}$ \\
\hline R8 & http://www.facebook.com/otempo \\
\hline R9 & $\begin{array}{l}\text { http://gl.globo.com/minas-gerais/noticia/2016/07/justica-concede-mandado-que-libera- } \\
\text { motorista-do-uber-em-bh.html }\end{array}$ \\
\hline R10 & $\begin{array}{l}\text { http://www.em.com.br/app/noticia/gerais/2016/06/11/interna_gerais,771695/motoristas- } \\
\text { do-uber-pedem-fim-da-violencia-contra-condutores-e-usuarios.shtml }\end{array}$ \\
\hline R11 & https://www.facebook.com/groups/983710271667221/ \\
\hline R12 & $\begin{array}{l}\text { http://www.em.com.br/app/noticia/economia/2017/02/15/internas_economia,847599/juiz- } \\
\text { reconhece-vinculo-empregaticio-no-uber.shtml }\end{array}$ \\
\hline R13 & $\begin{array}{l}\text { http://www.otempo.com.br/cidades/taxistas-de-bh-planejam-manifesta\%C3\%A7\%C3\%A30- } \\
\text { para-cobrar-posi\%C3\%A7\%C3\%A3o-do-mp-1.1021370 }\end{array}$ \\
\hline R14 & $\begin{array}{l}\text { http://www.otempo.com.br/cidades/projeto-que-pro\%C3\%ADbe-o-uber-\%C3\%A9-aprovado- } \\
\text { em-comiss\%C3\%A3o-da-assembleia-1.1090116 }\end{array}$ \\
\hline R15 & $\begin{array}{l}\text { http://www.otempo.com.br/cidades/motorista-do-uber-diz-ter-o-carro-danificado-por- } \\
\text { taxistas-em-contagem-1.1130903 }\end{array}$ \\
\hline R16 & $\begin{array}{l}\text { http://www.otempo.com.br/cidades/taxistas-pressionam-por-proibi\%C3\%A7\%C3\%A3o-do- } \\
\text { uber-em-belo-horizonte-1.1148029 }\end{array}$ \\
\hline R17 & $\begin{array}{l}\text { http://www.otempo.com.br/cidades/em-resposta-\%C3\%A0-viol\%C3\%AAncia-em-bh- } \\
\text { viagens-a-partir-do-uber-s\%C3\%A3o-de-gra\%C3\%A7a-1.1070812 }\end{array}$ \\
\hline R18 & $\begin{array}{l}\text { http://www.otempo.com.br/cidades/justi\%C3\%A7a-libera-atua\%C3\%A7\%C3\%A3o-da-uber- } \\
\text { em-todo-o-estado-1.1509468 }\end{array}$ \\
\hline R19 & $\begin{array}{l}\text { https://www.em.com.br/app/noticia/gerais/2015/12/09/interna_gerais,715515/uber-lanca- } \\
\text { campanha-contra-projeto-de-lei-que-pode-proibir-aplicativo.shtml }\end{array}$ \\
\hline R20 & $\begin{array}{l}\text { https://link.estadao.com.br/noticias/geral,uber-anuncia-chegada-a-belo-horizonte, } \\
\text { 10000030518 }\end{array}$ \\
\hline R21 & $\begin{array}{l}\text { https://www.em.com.br/app/noticia/gerais/2015/07/16/interna_gerais,669010/uber- } \\
\text { oferece-corridas-de-graca-e-taxistas-denunciam-concorrencia.shtml }\end{array}$ \\
\hline
\end{tabular}

Source: Elaborated by the authors. 
Finally, Moraes et al. (2017) point out that the researcher must broaden the voices to be heard, promoting the listening of what the actors say. Therefore, besides the description, two graphic representations were built (Venturini, 2010), namely: the mandala of actors disputing positions in controversies (Moraes et al., 2017) and the hierarchical tree of controversy (Cerretto \& Domenico, 2016).

\section{RESULTS AND DISCUSSION}

Uber was founded in 2009, by Garrett Camp and Travis Kalanick, with the initial proposal to offer a disruptive taxi-like service based on networked e-hailing. The app was launched for the Android and iOS smartphone platforms in 2010, offering cars in the city of San Francisco, California, as a "paid ride" (R1) service. According to Travis Kalanick, Uber's main idea was to provide means for people to share automobiles, in order to reduce the effects of phenomena such as traffic jams, emission of polluting gases, and parking lots, especially in large cities (R1).

Between 2010 and 2011, the company received nearly USD 50 million in investments (R2). In 2014, it was valued at USD 18.2 billion, with investors such as Google and Goldman Sachs. In 2015, Microsoft made a new investment, bringing Uber's market value to USD 51 billion. By offering a taxi-like service, but costing less than a traditional taxi fleet company, Uber has aroused concern and criticism from the taxi industry around the world. In May 2011, it received a judicial notification from the San Francisco City Traffic Department with the same charge (R3). In 2012, the California Public Utilities Commission fined Uber and other companies USD 20,000 each (R4). Similar episodes occurred at various locations in the United States. As the Uber business model expanded, similar problems were appearing around the world, such as in Australia, Canada, Portugal, France, and also Brazil (R3).

In the case of Brazil, specific departments of municipal governments regulate the work of taxi drivers, granting licenses at a high cost and high demand and are released in limited quantities. In general, taxi drivers' unions claimed that Uber was violating national laws governing the profession and triggered a series of protests and actions against the company (Binenbojm, 2016).

The first city to receive the app in Brazil was Rio de Janeiro, followed by Sao Paulo and Belo Horizonte (R20). Its arrival in the capital was accompanied by a wave of violence, protests, and aggression, bringing the presence of a 
diversity of human and non-human actors in this controversy, as well as the presence of this research.

\subsection{Uber: controversies in Belo Horizonte}

In September 2014, Uber do Brasil Tecnologia Ltda. arrived in Belo Horizonte, and even on the first day of the following month, the Sindicato Intermunicipal de Condutores Autônomos de Veículos Rodoviários (Sincavir), a union that serves taxi drivers and autonomous transporters from Minas Gerais, officially denounced the "illegality" of the app with the Belo Horizonte City Hall and with the Empresa de Transportes e Trânsito de Belo Horizonte (Traffic Department of Belo Horizonte - BHTrans), filing an application to ban it. The information contained on Sincavir's website regarding this action was accompanied by the allegation that Uber was an illegal transportation network.

In April 2015, Belo Horizonte taxi drivers, encouraged by the protests that took place in Sao Paulo, mobilized and articulated protests against Uber, pressing for its ban (R13). The demonstrations took effect and, in May, there was the creation of Bill 2.676/15, which provided for the prohibition of apps like Uber in the city. The project received a favorable opinion from the Transport, Communication and Public Works Commission of Minas Gerais Legislative Assembly (ALMG) on August 20 (R14). In social networks, there arose disputes between favorable opinion and the users.

If UBER is banned we will protest, we will hit the streets at peak hours and publicize all the deputies and councilors who voted against. We will also call the taxi drivers' unions in Procom about the expensive and precarious service provided by the taxi drivers (R5).

Controversy continued so intensely that on September 2nd, 2015, a man, apparently an Uber-accredited driver, was assaulted by taxi drivers. One the following day, a motorcade with taxi drivers was staged by approximately 200 taxi drivers against the app, directed to the Minas Gerais Public Prosecutor's Office (R15 and R16). On the fourth, fifth and seventh days of the same month, more aggression and persecution of app drivers were recorded. At the time, the police did not sue anyone, nor were Uber's drivers framed for clandestine transport.

In response to violent conflicts with drivers and users of the app, the company offered a free service in Belo Horizonte for routes of up to BRL 50 
(for three journeys per user), between 11 am and 6 pm, with the hashtag \#UberLoveDay (R17). When reporting this event, the newspaper Estado de Minas highlighted the following: "after crashes and threats involving taxi drivers, the Uber transport app launched its counterattack in an aggressive marketing strategy that offered free rides to passengers" (R21).

On the official Facebook page of the newspaper Estado de Minas, comments regarding the publication of this article revealed actors in controversy with the taxi drivers' traditional positioning and performance in the city. One of them commented: "It's funny that taxi drivers keep crying, but don't wonder why they are being replaced by Uber! \#uberloveday" (R6).

On October 3rd, 2015, a municipal Bill (prepared from a BHTrans report) was created in the City Council, providing for the creation of a Premium Tax category, prohibiting Uber in the configuration in which it operated in the city. This proposal would force drivers working for Uber to compete for one of the cards that licensed the taxi mode. On the page of the newspaper $\mathrm{O}$ Tempo, more actors spoke out against taxi drivers and BHTrans.

A bad proposal, like almost everything that involves BHTrans. City Hall needs to make sure that Uber does not become a monopoly and does not expel Uber by favoring taxi license owners who lease the service (R8).

In the same month, the president of the City Council of Belo Horizonte guaranteed support to taxi drivers and promised to discuss terms of the app's regulation bill. In November, the supplemental Bill 530/2015, which aimed to regulate the use of Uber in Brazil as a means of individual private transport (other than taxi), started its course in the Senate. On November 5th, the Belo Horizonte City Council requested BHTrans that taxi drivers who assaulted Uber's drivers should be punished. In the same week, taxi drivers carried out a new motorcade to mobilize efforts to approve Uber's regulatory/ban measures.

Amid so much controversy, on December 9th, Uber created another campaign to try to avoid the ban on the app in Belo Horizonte by Bill $1,797 / 15$. The action was promoted by sending an email to the residents of the capital registered on its database. Texts were sent that said: "On December 12th, Belo Horizonte will be 118 years old. And you know what may be the gift of the City Hall for the city? Backtrack" (R19), the email said. On the following week (12/16/2015), the city council changed, by approving a document that regularized the work of taxi drivers in $\mathrm{BH}$, 
criminalizing any assault committed on any person during the exercise of a driver's function.

In the second week of 2016 (09/01), Law 10,900/2016 was published in the Official Gazette of the Municipality (originated in PL 1,795/2015), prohibiting the use of Uber services in Belo Horizonte as offered by the app. The Law required drivers to be accredited with the city. However, Uber assured that it would continue working, supported by the Federal Constitution.

At the end of January, the Federal Court (STF) granted an injunction for Uber drivers to continue working for the app without registering with the city. If drivers suffered repression, a fine would be imposed on the agencies responsible for the enforcement of BRL 1,500 reais/day, as commented by a judge involved in the decision.

However, in addition to the disputes between taxi drivers, the State, and Uber have discussed so far, there is another factor that came into controversy with the multinational: the "partner" driver of Uber. This actor began to draw attention in social networks to the working conditions in the company and the low value paid to drivers.

Real cowardice and exploitation that Uber has been doing with its partner drivers. Paying unrealistic fees in the face of this crisis, gas prices, pressure, and many demands. UBER today is excellent only for the customer who travels in a car with air conditioning ... drinks water, gets candy ... They are (referring to passengers) treated well, for who pays "peanuts" for their travels. [...] (R8).

On June 11th, 2016 the drivers working for Uber set up a motorcade asking for more safety and regulation of work. Drivers advocated for the approval of a Bill to regulate the profession: "We need this regulation, even to end this confusion with taxi drivers. We don't rule out having other protests".

In line with these demands, in October 2016, an Uber driver in Belo Horizonte created a petition, charging the company for more rigorous passenger registration. A driver claimed that, since the acceptance of cash payment, there had been an increase in robbery and threats. Another driver said that he suffered from cheating by the passenger (R11).

In addition, discussions about labor issues prompted the involvement of one more actor at this time of controversy. On December 16th, 2016, prosecutors from the Labor Prosecution Service (MPT) announced that they would set up a research group on passenger transport apps, such as Uber. 
The group aimed to investigate the labor relations between companies and platform drivers, seeking to combat the precariousness of work. Meanwhile, Uber's partner drivers filed against the company, claiming the benefit of labor relations, with lawsuits in progress at the Regional Labor Court of the 3rd Region (TRT3), which covers Minas Gerais.

Regarding this moment, Uber reacted in early 2017 with a readjustment in the fixed cost of travel throughout the national territory. On January 17th, drivers linked to the app organized another motorcade, this time claiming better working conditions and security due to the increased number of burglaries due to "vulnerabilities" in the app, as discussed in the Uber BH Facebook Group/Customers \& Drivers. In the first half of February, the judge of the 33rd Labor Court of Belo Horizonte, Dr. Márcio Toledo Gonçalves, acknowledged the employment relationship between the company and the actor RLSF (partner driver) (R12). The company appealed and, in May 2017, won a lawsuit against the drivers. The decision, in the second instance, was made unanimously.

Finally, disputes over the legitimacy of services provided by drivers operating on the Uber platform were marked by a new event. On August 16th, 2017, judges of the Minas Gerais Court of Justice voted in favor of the release of private transportation apps throughout the state. The magistrates analyzed the so-called Repetitive Demand Resolution Incident (IRDR), regarding the legality of the service provided by companies such as Uber. This decision created a kind of jurisprudence for all actions related to this controversy (R18). From that moment on, the controversies were no longer followed, as the elements of the decision were enough to understand the study proposal.

The narrative shows that a sociotechnical innovation, in this case, technology, and its implementation, does not go in a linear and uniform way. That is, it involves a complex network of human and non-human actors in dispute (Latour, 2016). This was evident at both times, when Uber was strengthening, and when its existence/permanence was threatened. In this sense, Pinch and Bijker (1984) show that technologies are not defined by purely technical criteria - they depend on consumer interests, political interests, and diversity of collectives. As the authors show, before stabilizing as we know it today (its shape, its use, etc.) there are "different" competing cycles. The same is true for Uber, which, since its inception, has undergone several changes - sometimes vying with and sometimes forming alliances with laws, taxi drivers, politicians, users, competitors, researchers, and drivers. 


\subsection{The actors and controversies that mark the disruption network studied}

To understand this reality, the focus was sought on the actors involved. Remember that Uber actors or actants are not just taxi drivers, Uber drivers, or users. According to Law and Mol (2008, p. 74), "an actor is a moment of indetermination that generates events and situations" so that the focus on this definition is on the actions that the actors perform and their different directions and impacts. Thus, the study of the controversies that marked the disruptive innovation caused by the emergence of Uber in Belo Horizonte involved the action of different human and non-human actors that promulgated this network (Figure 4.2.1).

\section{(Figure 4.2.1)}

\section{MANDALA OF ACTORS DISPUTING POSITIONS IN CONTROVERSIES RELATED TO UBER'S PERFORMANCE}

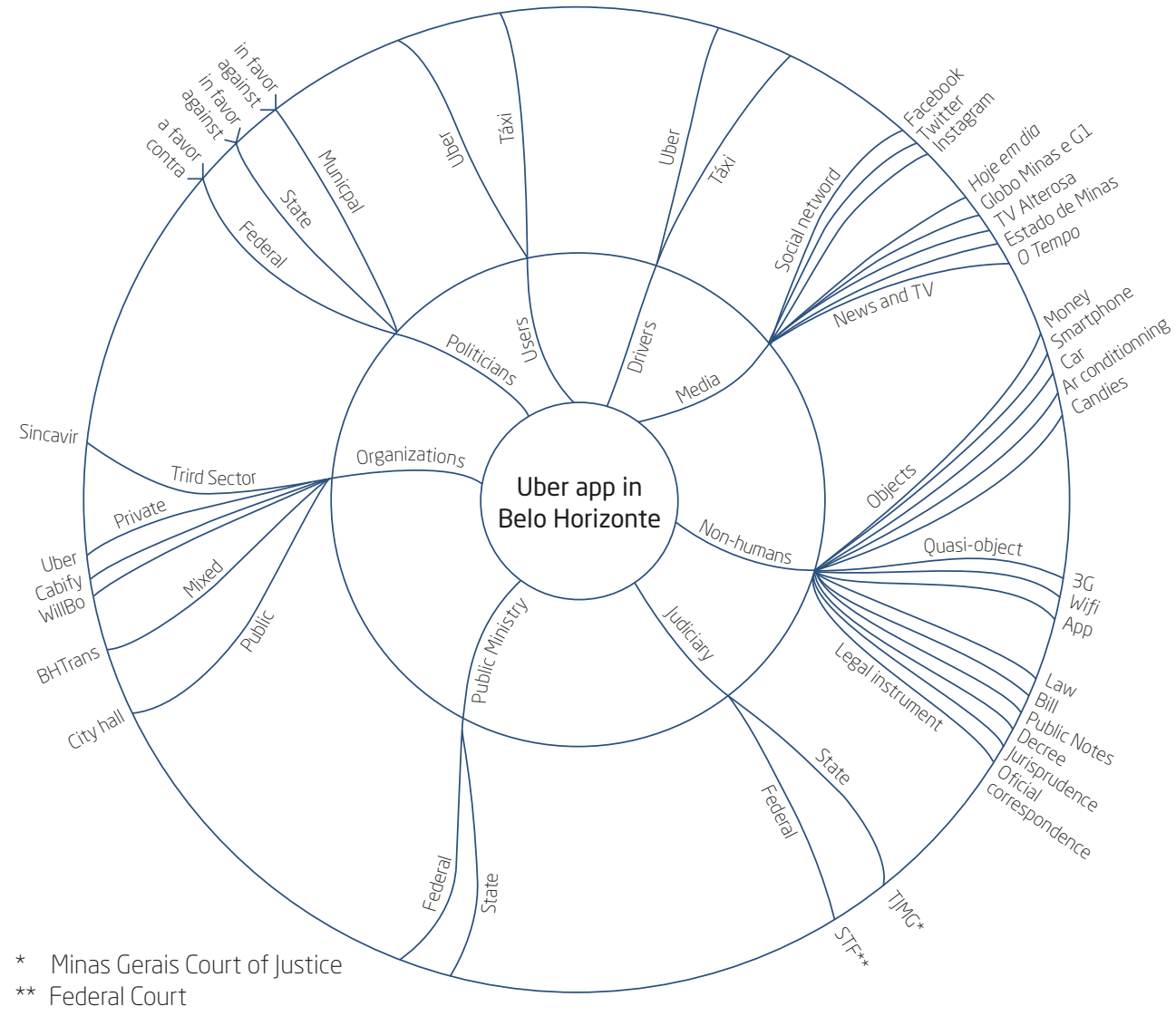

** Federal Court 
As it can be seen, the actors dispute controversial positions. To understand these confrontations, a cognitive map (Figure 4.2.2) was elaborated in a proposal close to a hierarchical tree (Cerretto \& Domenico, 2016). To this end, the very existence of the app developed by Uber was defined as a central controversy in the formation of this network. From this controversy, different themes emerged which, in turn, presented different positions, highlighting the actors that supported them, as well as the arguments used by them in this process.

From the insertion of Uber in Belo Horizonte in September 2014, the first theme that marks this disruption is related to the legitimacy of the service offered by the company, enacted by a set of actors and devices. The discussion about the legitimacy of Uber promoted intense debates, forming networks of actors who sought to defend different positions. These positions can be represented on three axes. The first one defends the app ban, advocated, above all, by taxi drivers (Sincavir), most of the city councilors of Belo Horizonte, BHTrans agents, and taxi users who identified with the position. This axis is based on the notion that this innovation undermined the work of taxi drivers already in the market, with the complaint that Uber's partner drivers were acting in a clandestine manner since they did not conform to the norms established for the regulation of the operation of taxi drivers. Taxi drivers and the criticism are related to Uber's multinational character, which had as its interest only the exploitation of Brazilian workers. The second axis defends Uber regulation and it was advocated by some councilors and deputies, some agents of BHTrans, Belo Horizonte City Hall, and legal provisions such as Bills, Laws, Decrees, Oficial Correspondence, etc., as well as users of urban mobility and some Uber drivers. The position was based on two arguments: 1. the need for greater control of operations involving Uber, considering their impact on this market; and 2. the need for regulation upholding equality among Uber agents, especially taxi drivers and drivers, so that, once formalized by the State, more equitable conditions would be in place to operate. Finally, the third position, around the legitimacy of the arrangement, was marked by actors who defended the unchanging of the market conditions, especially the directors of Uber itself, some users of services, and jurisprudence promulgated by some magistrates, as well as their own sociotechnical configurations of the app. This position defended Uber's promotion of innovation and, therefore, should not be regulated, as well as a criticism of the Brazilian State's action directed at the regulation and control of all economic exchanges, which could lead to greater bureaucratization of services. 


\section{(Figure 4.2.2)}

\section{HIERARCHICAL TREE OF THE UBER BELO HORIZONTE CONTROVERSY}

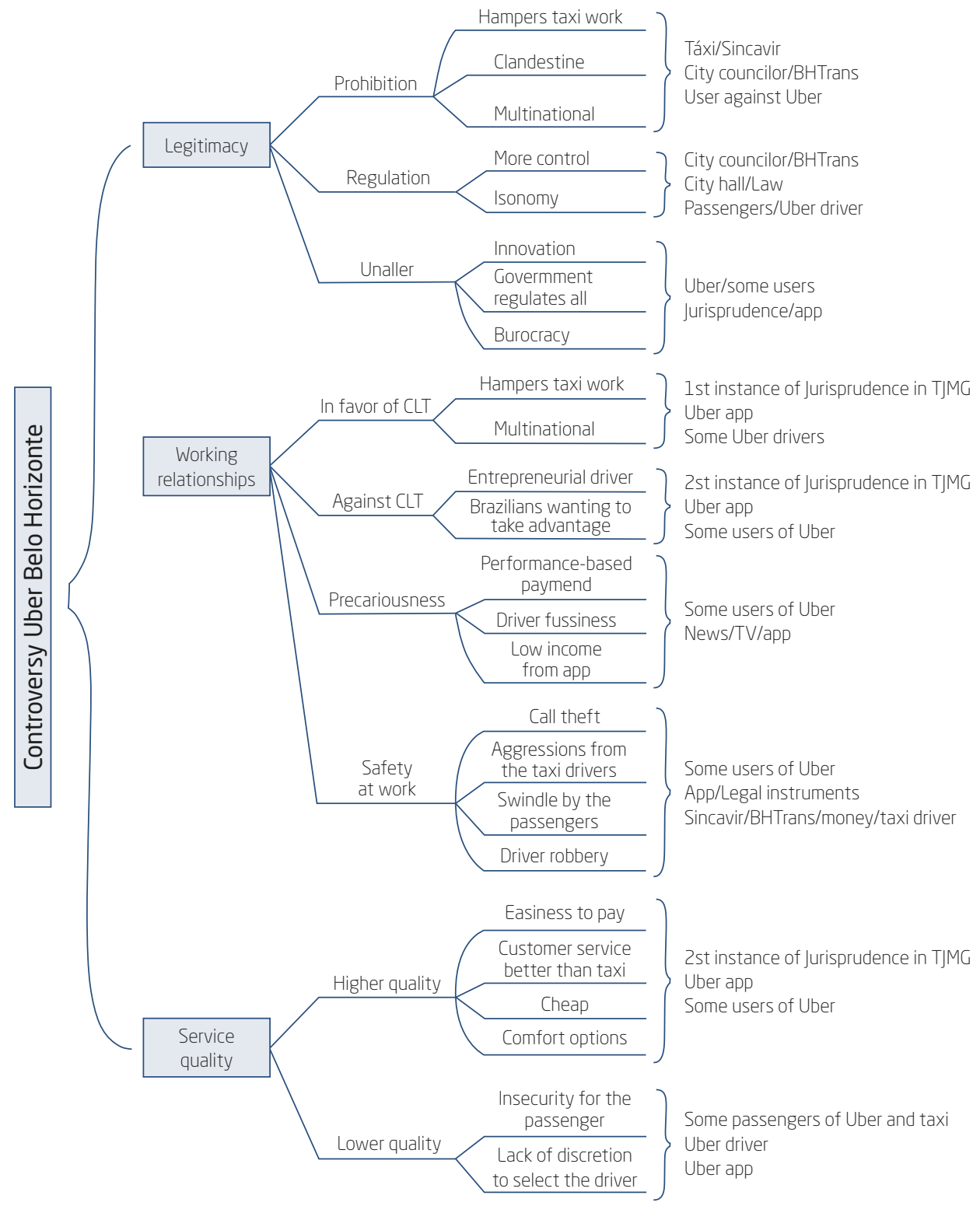

Source: Elaborated by the authors.

In turn, the second issue that marks this controversy concerns the dispute over labor relations, especially from the relationship among drivers, the 
app, and Uber. In this sense, the actors that constitute this theme are figured in four positions. The first concerns the recognition of the involvement between Uber and drivers as an employment relationship, which should then be regulated under the Consolidation of Labor Laws (CLT). The main actors involved in this position were legal actors in the first instance, drivers who triggered legal provisions and the app's own configurations that allowed the production, in the first instance, of a case law favorable to the recognition of labor laws in this network. On the other hand, other actors took opposite positions, arguing that there were no working relationships between Uber, the app, and drivers. In these disputes, arguments were used that claimed that the liberal and enterprising nature of the activity performed by drivers and Uber (and devices linked to its position) was only an intermediary between the service and the users. In addition, an argument was criticized by some drivers who triggered legal provisions, that is, close to the previous position, as "Brazilians wanting to take advantage." In this position, there were actors, such as some drivers who worked for the Uber app, as well as managers of the company itself, jurisprudence, and some users. Within this theme, another position referred to the debates around the precariousness of work promoted by translations among network actors, especially drivers and devices of the app. On the one hand, drivers, as well as some media users and vehicles, claimed that driver-based remuneration promoted increased competition and long working hours (some drivers even worked for 18 straight hours a day), which incurred damage to health. On the other hand, some drivers working for the app, as well as other users, backed up the previous arguments, arguing that the individuals who performed these activities recognized the risks of such work. In addition, disputes involving labor relations also pervaded positions held by actors regarding occupational safety. Thus, arguments were defended, among which, stood out the theft of vehicles, assaults by taxi drivers, passengers cheating, and robberies of drivers.

Regarding the last issue that constitutes the controversies analyzed in this network, we highlight the positions and arguments related to the quality of service. In this sense, two opposing positions are explored. The first one involves the higher quality of urban mobility provided by Uber's disruption. Affiliates of this position employed arguments such as greater ease of payment for services, better pricing, better customer service over the taxi, and the ability to choose the comfort of travel. Among the actors who made up this position were: some drivers who worked for Uber, the app, money (which, paradoxically, is regarded as an actor that promoted job insecurity), smartphones, candies, air conditioning, signal, free Wifi, and different radio 
stations, among others. Contrary to previous arguments, other actors argued that the arrangement promoted by Uber caused lower quality service. This notion was reproduced from arguments such as the insecurity to which some users were submitted and the lack of criteria for selecting Uber drivers, which could incur harassment and aggression to users, caused by these actors.

In short, the set of themes, positions, and arguments performed by different actors making up this network reflect the controversies surrounding the disruption promoted by Uber (from its characteristic devices) in Belo Horizonte.

\subsection{Contributions to the study of disruptive innovations: controversies, enacting, and multiplicity}

Controversies are common and frequent in performative processes such as disruptive innovations, in which actors are inserted in the existence of sociomaterial agencies of different realities. Several studies have been conducted on the market building, stabilization, and heterogeneity. For example, Medeiros et al. (2014) show that the publishing market has long been stabilized (with bookstores, publishers, authors, transportation, printers, etc.); however, the internet changed business relationships that destabilized and, subsequently, stabilized the market (now with websites, tablets, e-readers, publishers, ebooks, etc.). Something similar can be observed in the case of Uber, in which, hitherto, the stable urban mobility market underwent significant changes with the emergence of the app. The procedures in this article, namely, the mandala of the actors in dispute and the hierarchical tree, were important instruments for reaching this understanding: innovations destabilize structures and generate externalities (Callon, 1998; Leme \& Rezende, 2018).

For Medeiros et al. (2014), and Leme and Rezende (2018), market construction involves the notion of framing and overflow, concepts based on Callon (1998). Framing "encompasses the process of calculated practices, such as rules, regulations, agreements, contracts, transactions, among others [...]" (Medeiros et al., 2014, p. 157). For Leme and Rezende (2018), framing is a process of stabilization of market arrangements - actors submit to rules (Callon, 1998). However, actions can go beyond barriers and in this case "interfere with the actions of other agents that are not necessarily related to the economic exchange that has occurred" - overflowing (Medeiros et al., 2014, p. 158).

Overflow is "the result of the impacts that exchange has on society as a whole, even if the elements have nothing to do with exchange" (Medeiros 
et al., 2014, p. 158). The notion of overflow indicates that the framework is fragile and partial, and the stability of entities is provisional and relational (Callon, 1998). This could be seen as Uber's app began to enact new realities in the urban mobility market, breaking with the frameworks and promulgating new relationships between actors, many of them represented in the controversies. In the case discussed in this article, the spillover was also directed, among other recorded cases of violence between actors (Uber partner drivers, taxi drivers, service users, and automobiles, among others) and political-legal disputes involving Bills.

Therefore, this study of Uber reiterates the fact that markets are hybrid, collective, and with social practices that involve the use of a particular object (Callon, 1998; Kjellberg \& Helgesson, 2006). It has also been found that uncertainty (Latour, 2012) is present in markets beyond any stability. One of the sources of uncertainty, according to Latour (2012), is that there are no groups, but only group formation. This was observed when, at some point, Uber drivers, in a coalition (in favor of the company Uber do Brasil), came to pressure the company itself, especially regarding the non-recognition (by the platform developer) of relationships working with their driver partners.

This uncertainty does not apply only to representations and discourses. The differential of the ANT perspective is to understand that this fragility is present in all sociomaterial entities. Therefore, a technological artifact "apparently unique may be being enacted at the same time in the most different practices, in different locations, constituting, in fact, multiple objects" (Ferreira \& Lessa, 2019, p. 7). This notion was present in the urban mobility market of Belo Horizonte, having seen the different technologies enacted by the various actors through their network relations: 1. user technology; 2. provision of services; 3 . economic issues; and 4. Uber drivers. It is worth noting that, in each practice, the Uber app is differently accented. Strictly speaking, it is not the same object. It can be seen that the existence of the artifact (app) is linked to a practice, and therefore an enacted reality (Mol, 2002).

In this sense, the present article is not only about investigating how a disruptive innovation is constructed as a "fact" by accompanying its stabilization processes, but also about advancing the study of innovations from the notion of enactment (Mol, 2002; Ferreira \& Lessa, 2019), understanding that among technologies, organizations, and society there is a constitutive tangle marked by sociomateriality and multiplicity. In Uber's case, we understand that the app is enacted in different ways, in different practices, hence, 
"the various modes of enactment lead to a multiplicity of objects constituted in various sociomaterial configurations which are equally and distinctly real" (Ferreira \& Lessa, 2019, p. 6). This is reminiscent of the study by Law and Mol (1995) on Doppler that was enacted as an instrument for the diagnosis of obstructed veins, as a technology that helps to assess the health of a fetus, and as a diagnostic object under evaluation. In addition to the Doppler case, Law and Mol's (2008) work on the actor-enacted is also a reference. For the authors, in each of the practices "a sheep" was something different. They described a total of four sheep, namely, the sheep in the veterinary sheep, the epidemiological sheep, the economic sheep, and the farming sheep.

Furthermore, from the point of view of technology discussions, this paper has shown that technology is not independent of classical perspectives. In line with social constructivism (Pinch \& Bijker, 1984), the meaning of technology arises in different social groups, not having a single technical logic that is free of values. Therefore, neither the urban mobility market in Belo Horizonte nor the Uber app are distinct entities endowed with the attribute of stability - they are built relationally. In this sense, "the relations and divisions between humans and technologies are not pre-established or fixed, but enacted in practice" (Ferreira \& Lessa, 2019, p. 5). In addition to the discussion by Pinch and Bijker (1984), the recent perspectives of the ANT reveal that these are processes in which enacting constitutes different realities in their multiplicities.

\section{FINAL CONSIDERATIONS}

It was noticed in this article that entities enact each other and provide their existence mutually. Thus, from the collected data, it is stated that acting and being enacted occur together, and an actor does not act alone. Moreover, an act-enactant is not in control, since acting is not controlling. The technology presented here is at the crossroads of various practices, each of which enacts this technology differently. The study presents some versions of technologies. First, user technology that is a form of urban mobility, with superior quality, faster service, practicality, and a fair price; however, it is difficult to understand whether the technology is safe or not, as it also depends on the care of Uber in selecting drivers, although both the user and the company can observe and evaluate the driver through technology.

Second, urban mobility service technology was viewed differently as a geographically located set, and the likelihood of finding an available driver was 
given at a distance: drivers willing to take short trips or to go to places where one is not sure of being safe, as slums, are less available (fewer peripheral drivers and slum areas are in the south-central area of Belo Horizonte).

Third, the technology of economic issues. In this reality, the purchase and sale of cars manufactured from 2008 particularly increased, due to the insertion of UberX (more popular cars), so the market price of these cars has risen, and today it is common to find Uber drivers on social networks negotiating the rental of cars for a certain period of time. In addition, the state government instituted in the second instance that there is no labor relationship between Uber and the driver, reinforcing arguments that the driver would be an entrepreneur. This was of utmost importance for the "enactment" economy of the technology.

Fourth, the technology of the Uber driver. In this reality, technology manifests itself in relation to a diversity of human and non-human actors and not just a single individual with an economic value. One of the practices that can be performed through the app is to rate the quality of service provided by the driver. This grade is given by the Uber user, from 0 to 5 . Drivers need to remain at an average grade of 4.5 , otherwise, they are disqualified by the company. Therefore, it is common in Uber driver communities to find expressions such as: "my eyes shine on the five stars" and "faith in God and focus on the five stars."

That said, it is noteworthy that, when we think of disruptions based on information technology, you realize that they are performing in new markets, in various areas of society, such as music (in the case of Spotify), digital currency (Bitcoin), cinema (Netflix), hospitality (Airbnb), education (e-learning), reading (e-readers), and transportation, focusing on Uber, as shown in this research. From this, the technologies that participate in the disruption process, instead of carrying representations, actually perform new entities that need to apply for controversy, in order to be fulfilled. Therefore, disruption is understood as a controversial process, in which assemblages perform new practices in once stable markets.

Another important finding concerns the relations between antagonistic actors: Uber drivers and taxi drivers. It can be seen that the reality formed between taxi drivers and other adjacent actors in the realm of taxis is closer to actors connected to the state. In turn, the Uber driver, as well as the company and the closest actors, perform closer relationships with users of urban transport. Probably, this explains why mobilizations happened against the establishment of Uber by the government, as well as demonstrations against these actors by many users, especially in social networks. It is 
understood that, for this set of disruptive innovations to be set up in black boxes, it may be necessary for actors representing Uber to seek to establish new associations with state actors.

As a research agenda, future studies may explore the role of marketing in the construction and dissemination of markets. Thus, it is important to study market practices (transaction, representation, and normative) (Kjellberg \& Helgesson, 2006), taking Uber as the object of study. Ethnographic research could also be conducted using more immersive data collection methods, as proposed by Latour (2012). Finally, it is noteworthy that this work allowed us to visualize how the actants become what they are and how they act, as well as enact realities, and that the moments in which they find themselves may clash or complement each other. The article's contribution lies in being able, even momentarily, to capture the multiplicity of disputed realities in disputes and make them understandable to the reader.

\section{ABRINDO CAIXAS-PRETAS DAS INOVAÇÕES DISRUPTIVAS: CONTROVÉRSIAS ENVOLVENDO A UBER EM BELO HORIZONTE}

\section{$\int$ RESUMO}

Objetivo: Busca-se neste artigo compreender as controvérsias presentes a partir da inserção de uma tecnologia disruptiva em um novo modelo de negócios, a Uber, no mercado de mobilidade urbana de Belo Horizonte.

Originalidade/valor: A teoria ator-rede permite descrever uma inovação como técnica e social, bem como identificar as sociomaterialidades que estão a enactar as múltiplas realidades a partir da mobilização em controvérsias. A proposta é original ao investigar como uma inovação disruptiva é construída como "fato", acompanhando seus processos de desestabilização e construção de um novo mercado. Houve avanços também na aplicação do conceito de enactar e multiplicidade no estudo de inovações disruptivas.

Design/metodologia/abordagem: A pesquisa foi operacionalizada a partir da própria teoria ator-rede, utilizando-se da cartografia para seguir os atores em suas controvérsias. Os dados foram advindos, principalmente, de jornais, postagens em redes sociais e materiais jurídicos acessados 
via internet (de dezembro de 2014 a julho de 2017). Para a apresentação dos resultados, utilizaram-se a mandala de atores que disputam posições em controvérsias e a árvore hierárquica das controvérsias.

Resultados: $\mathrm{O}$ arranjo foi marcado por diversas controvérsias que versavam sobre a legitimidade do aplicativo, as relações trabalhistas estabelecidas pela inovação e a qualidade dos serviços prestados, cada uma sustentada por diferentes atores, posições e argumentos. Identificaram-se quatro tipos de tecnologia enactada nesse arranjo: 1. tecnologia do usuário; 2. da prestação de serviço; 3. das questões econômicas; e 4. do motorista Uber. Entendeu-se com isso que a tecnologia Uber é múltipla, enactada de formas diferentes, em diferentes práticas, e que o arranjo sociotécnico ainda não se estabilizou.

\section{PALAVRAS-CHAVE}

Cartografia das controvérsias. Economia de compartilhamento. Teoria ator-rede. Tecnologia e sociedade. Enactar.

\section{REFERENCES}

Araujo, L. (2007). Markets, market-making and marketing. Marketing Theory, $7(3), 211-226$.

Binenbojm, G. (2016). Novas tecnologias e mutações regulatórias nos transportes públicos municipais de passageiros: Um estudo a partir do caso Uber. Revista de Direito da Cidade, 8(4), 1690-1706.

Blanchet, V., \& Depeyre, C. (2016). Exploring the shaping of markets through controversies: Methodological propositions for macromarketing studies. Journal of Macromarketing, 36(1), 41-53.

Çalışkan, K., \& Callon, M. (2010). Economization, part 2: A research programme for the study of markets. Economy and Society, 39(1), 1-32.

Callon, M. (1986). Some elements of a sociology of translation: Domestication of the scallops and the fishermen of St Brieuc Bay. In J. Law (Ed.). Power, action and belief: A new sociology of knowledge? London: Routledge.

Callon, M. (1998). An essay on framing and overflowing: Economic externalities revisited by sociology. The Sociological Review, 46 (suppl. 1), 244-269. 
Callon, M. (2004). The role of hybrid communities and socio-technical arrangements in the participatory design. Journal of the Center for Information Studies, 5(3), 3-10.

Callon, M., \& Muniesa, F. (2005) Economic markets as calculative collective devices. Organization Studies, 26(8), 1229-1250.

Cerretto, C., \& Domenico, S. M. R. (2016). Mudança e teoria ator-rede: Humanos e não humanos em controvérsias na implementação de um centro de serviços compartilhados. Cadernos EBAPE.BR, 14, 83-115.

Ferreira, R. C. R., \& Lessa, B. S. (2019). Enactando tecnologias: A noção de enactment como possibilidade analítica para o estudo das tecnologias nas organizações. Décimo Encontro de Estudos Organizacionais da Anpad - EnEO, Fortaleza, CE, Brasil.

Kjellberg, H., \& Helgesson, C. F. (2006). Multiple versions of markets: Multiplicity and performativity in market practice. Industrial Marketing Management, 35(7), 839-855.

Latour, B. (1999). On recalling ANT. In J. Law \& J. Hassard, J. Actor-network theory and after. Oxford: Blackwell.

Latour, B. (2012). Reagregando o social: Uma introdução à teoria do ator-rede. Salvador: Edufba.

Latour, B. (2016). Cogitamus: Seis cartas sobre as humanidades científicas. São Paulo: Editora 34.

Law, J., \& Mol, A. (2008). The actor-enacted: Cumbrian sheep in 2001. In C. Knappett \& L. Malafouris. Material agency: Towards a non-anthropocentric approach. New York: Springer.

Law, J., \& Mol, A. (1995). Notes on materiality and sociality. The Sociological Review, 43(2), 274-294.

Leme, P. H. M. V., \& Rezende, D. C. de (2018). A construção de mercados sob a perspectiva da teoria ator-rede e dos estudos de mercado construtivistas (EMC). Revista Interdisciplinar de Marketing, 8(2), 133-151.

Medeiros, J., Vieira, F. G. D., \& Nogami, V. K. C. (2014). A construção do mercado editorial eletrônico no Brasil por meio de práticas de marketing. Revista de Administração Mackenzie, 15(1), 152-173.

Mol, A. (2002). The body multiple: Ontology in medical practice. Durham: Duke University Press.

Moraes, R. L., Andion, C., \& Pinho, J. L. (2017). Cartografia das controvérsias na arena pública da corrupção eleitoral no Brasil. Cadernos EBAPE.BR, 15(4), 846-876. 
Pinch, T. J., \& Bijker, W. E. (1984). The social construction of facts and artefacts: Or how the sociology of science and the sociology of technology might benefit each other. Social Studies of Science, (3), 399-441.

Tonelli, D. F. (2016). Origens e afiliações epistemológicas da teoria atorrede: Implicações para a análise organizacional. Cadernos EBAPE.BR, 14, 377-390.

Venturini, T. (2010). Diving in magma: How to explore controversies with actor-network theory. Public Understanding of Science, 19(3), 258-273.

\section{AUTHOR NOTES}

Kelly C. Vieira, Ph.D. from the Department of Administration and Economics, Federal University of Lavras (Ufla); André L. Paiva, master from the Department of Administration and Economics, Federal University of Lavras (Ufla); Valderí C. Alcântara, Ph.D. from the Department of Administration and Economics, Federal University of Lavras (Ufla); Daniel C. Rezende, Ph.D. from the Centre of Research in Agriculture and Development (CPDA), Federal Rural University of Rio de Janeiro (UFRRJ).

Kelly C. Vieira is now a post-doctoral student at the Department of Administration and Economics of Federal University of Lavras (Ufla); André L. Paiva is now a doctoral student at the Department of Administration and Economics of the Federal University of Lavras (Ufla); Valderí C. Alcântara is now professor of Management at Minas Gerais State University (UEMG); Daniel C. Rezende is now an associate professor at the Department of Administration and Economics of Federal University of Lavras (Ufla).

Correspondence concerning this article should be addressed to Valderí C. Alcântara, Rodovia MG-260, 33, Cláudio, Minas Gerais, Brasil, CEP 35530-000.

E-mail: valderidecastroalcantara@gmail.com

EDITORIAL BOARD

Editor-in-chief

Gilberto Perez

Associated Editor

Maurício Reinert do Nascimento

Technical Support

Vitória Batista Santos Silva
EDITORIAL PRODUCTION

Publishing Coordination

Jéssica Dametta

Layout Designer

Emap

Editorial Intern

Paula Di Sessa Vavlis

Graphic Designer

Language Editor

Daniel de Almeida Leão 